일 반논문-07-12-1-02

$$
\begin{gathered}
\mathrm{T}-\mathrm{DMB} \text { 를 위한 통합 측정 및 분석 시스템 } \\
\text { 김 상 훈 }{ }^{\text {a }} \text {, 김 영 민 }{ }^{\mathrm{a})} \text {, 김 만 식 }{ }^{\mathrm{a})} \text {, 김 규 영b) }
\end{gathered}
$$

\title{
The Integrated Measurement and Analysis System for T-DMB
}

\author{
Sang-Hun $\mathrm{Kim}^{\mathrm{a})^{\ddagger}}$, Young-Min $\mathrm{Kim}^{\mathrm{a})}$, Man-Sik Kim${ }^{\mathrm{a})}$ and Gyu-Young Kim ${ }^{\mathrm{b})}$
}

\begin{abstract}
요 약
휴대 이동 방송을 위한 T-DMB(Terrestrial - Digital Multimedia Broadcasting)가 2005년 12월 수도권에서 본방송을 시작 하였다. 현재 다양한 양방향 데이터 서비스의 개발과 T-DMB 방송망 확장이 진행 중이며, 조만간 지역 T-DMB 사업자도 선 정될 예정이다. T-DMB의 RF 커버리지를 최적화하기 위해서는 서비스 영역을 산출하고 음영 지역을 해소하는 것이 중요하지 만, 이를 지원하는 전문적인 시스템이 없어 많은 예산, 인력, 시간이 소요되었다. 송신기의 시간 및 주파수 동기, 송신소 사이 의 거리, 송신 전력의 크기를 조절해야 하는 T-DMB 방송망 구축에 있어서 SFN(Single Frequency Network)의 특성을 고려 한 축정이 필수적이다. 또한 T-DMB의 커버리지를 산출하기 위해서는 이동 측정, 다각적인 수신 품질 분석을 위한 측정 항목 지원, 방대한 측정 데이터의 효율적인 관리, 전자지도를 이용한 측정 결과 분석이 필요하다. 본 논문에서는 위의 사항을 고려 하여 T-DMB에 적합한 새로운 측정 시스템에 대한 요구 사항을 도출하고, T-DMB를 위한 통합 측정 및 분석 시스템을 제안 하였다. 제안한 시스템은 KBS T-DMB 방송망 구축과 필드 테스트에 적용되어 효율성과 정확성을 입증하였다.
\end{abstract}

\begin{abstract}
T-DMB(Terrestrial-Digital Multimedia Broadcasting) for portable and mobile broadcasting service was officially launched in the metropolitan area of Korea in December 2005. The development of interactive data services and the expansion of T-DMB network have been now progressed, and the regional T-DMB broadcasters will be selected in the near future. Although it is important to evaluate service area and reduce a fringe area for optimizing $R F$ coverage of T-DMB, there was no professional system to support those works, and therefore lots of resources in budget, manpower and time were required. The measurement considering characteristics of SFN(Single Frequency Network) is essential in the implementation of T-DMB network which needs to control synchronization, spacing and output power of transmitters. In addition, mobile measurement, enough measured parameters for many-sided analysis of reception quality, efficient management of enormous measured data and representation of measured results on the electronic map are also important in evaluating service area. In this paper, we derived requirements for a new measurement system in T-DMB by considering the above details, and we proposed and developed an integrated measurement and analysis system. The developed system was applied to the implementation of T-DMB network of KBS and field tests, and it proved its efficiency and accuracy in result.
\end{abstract}

Keywords: T-DMB, SFN, Measurement, Analysis, Coverage, Field Test

\footnotetext{
a) 한국방송 방송기술연구탐

Broadcast Technical Research Team, KBS

b) 한국방송 디지털전환팀

Digital Conversion Team, KBS

; 교신저자 : 김상훈(shkbs@kbs.co.kr)
} 


\section{I. 서 론}

T-DMB는 다중경로 페이딩(Multipath Fading)과 Rayleigh 채널과 연관된 이동 수신에서 발생하는 여러 다른 문제들 에 강인한 COFDM(Coded Orthogonal Frequency Division Multiplexing)을 사용하므로 기존의 국내 방송 매체들과는 달리 SFN 형태의 방송망 구성이 가능하다 ${ }^{[112]}$. SFN은 주파 수를 절약할 수 있고, 네트워크 이득으로 인한 수신 전계 강도 상승을 제공한다는 측면에서 넓은 지역을 커버하는 방송망 구성에 매우 효율적이다. T-DMB SFN에서 수신기 에 입력되는 신호는 주 신호와 다중 경로 신호의 합으로 구성된다. 일반적으로 지연된 다중 경로 신호는 인접한 심볼들 사이에 간섭을 유발(ISI: Inter Symbol Interference) 하는데 보호 구간(Guard Interval: 246us) 이내에 수신된 신호는 간섭을 유발하지 않고 $\mathrm{S} / \mathrm{N}$ 비(Signal to Noise Ratio)를 향상시켜 수신 성능을 개선하는 효과를 제공한 다 $^{[3] 44[1][5]}$.

T-DMB 방송망을 완성하기 위해서는 일반적으로 $\mathrm{SFN}$ 구성, 커버리지 산출, 음영 지역 해소 과정을 거치 게 된다.

ETS 300 799에 의하면 SFN을 구성하기 위해서는 모든 송신기가 동일한 데이터(the same data)를 동일한 시간(at the same time)에 동일한 주파수(at the same frequency)에서 전송해야 한다 ${ }^{[6}$. 이러한 조건이 어긋나면 다른 송신기들의 신호가 서로 간섭을 유발하거나 OFDM 심볼을 구성하는 다수의 캐리어들 간의 직교성을 상실하게 된다. 그 결과로 $\mathrm{S} / \mathrm{N}$ 비가 감소하게 되고, 이동 수신에서 발생하는 도플러 효 과(Doppler Effect)로 인한 주파수 편이에 취약해진다. ETS 300 799의 조건 이외에도 SFN을 구성하기 위해서는 수신 점 신호를 구성하는 모든 송신기들은 보호 구간에 의해 결 정된 거리 $(73.8 \mathrm{~km})$ 이내예 위치해야 하고, 보호구간을 벗어 나 위치한 원거리 송신기에 의한 간섭이 최소화 되도록 조 절되어야 한다다][s].

커버리지를 산출하기 위해서는 방송 수신 품질을 반영할 수 있는 전계강도 등과 같은 항목들에 대한 측정이 필수적 이다. 수신을 위한 유효 전계강도(Effective Field Strength) 를 확보한 경우에도 보호 구간을 벗어나는 지연 신호에 의
해 수신 품질이 저하될 수 있으므로 이러한 사항을 확인하 기 위한 항목들을 측정할 필요가 있다.

음영 지역을 해소하기 위해서는 중계망(On Channel Repeater) 구축과 최적화가 필요하다. 중계기 출력 및 송신 안테나 높이, 중계기와 주 송신기 사이의 거리가 증가 할수 록 중계기 출력 신호가 보호 구간을 벗어나 간섭으로 작용 할 가능성이 증가한다 ${ }^{[4]}$. 그러므로 정확한 중계망 구축을 위해서는 중계망 구축 전후의 수신 품질에 대한 비교 측정 이 필수적이다.

안정적인 T-DMB 서비스를 제공하기 위해 위의 과정이 중요하지만 이를 지원하는 전문적인 시스템이 없어서 많은 예산, 인력, 시간이 소요되었다. 이를 해결하기 위해 본 논 문에서는 새로운 측정 및 분석 시스템을 위한 요구 사항을 도출하고, T-DMB을 위한 통합 측정 및 분석 시스템을 제안 하였다.

본 논문은 피장에서 기존의 측정 시스템에 대하여 설명하 고, 피장에서 새로운 측정 시스템을 위한 요구 사항에 대하 여 설명한다. IV장에서 제안한 시스템에 대하여 설명하고, $\mathrm{V}$ 장에서는 제안한 시스템을 필드 테스트에 적용한 결과 보 여주며, 마지막으로 VI장에서 결론을 맺는다.

\section{II. 기존의 측정 시스템}

기존의 측정 시스템에는 유럽의 디지털 오디오 방식인 Eureka-147 DAB(Digital Audio Broadcasting)에서 오디오 서비스의 커버리지 측정과 분석에 적용된 독일 Rohde Schwarz사의 Romes, 독일 VAD사의 UMODIR이 있으며, $\mathrm{T}-\mathrm{DMB}$ 에서 전계강도와 비트 오류율 측정을 지원하는 저 자의 이전 논문에서 제안한 통합 이동 측정 시스템이 있다 [7][8][9][10]

Romes는 유럽 Eureka-147 DAB의 도입과 성능 검증을 위한 목적으로 '지상파 디지털 라디오 방송 추진 위원회' 산하의 '실험 방송 전담반'에서 주관하여 $\mathrm{KBS}, \mathrm{MBC}, \mathrm{SBS}$, 전파 연구소에 의해 2002년에 실시된 'DAB 실험 방송'의 이동 측정 시스템으로 도입되어 사용되었다 ${ }^{[7]}$. Romes는 전 계강도 측정기, DAB 기준 수신기, GPS(Global Positioning 
System) 수신기, 거리 떨스 발생기, 통합 시스템 패널, 측정 소프트웨어, 분석 소프트웨어로 구성되어 있으며, 전계강도 와 $\mathrm{DAB}$ 기준 수신기에서 제공하는 $\mathrm{DAB}$ 오디오 신호의 수 신 품질에 관한 정보를 수집하여 저장한다. 측정 결과의 평 가 및 분석을 위해서는 측정 결과를 다양한 형태로 가공하 고 이를 지리 지형 정보와 같이 표현하는 것을 지원하는 분 석 소프트웨어가 필수적인데 Romes에서 지원하는 분석 소 프트웨어는 측정 결과를 MapInfo사의 MapX4.5 기반의 전 자지도에 색상만을 구분하여 도시하는 것이 전부였다. 이 러한 이유로 'DAB 실험 방송'에서는 별도의 분석 소프트 웨어를 개발하여 활용하였다. 그러나 Romes가 측정 결과 를 $\mathrm{cmd}$ 라는 자체의 고유 파일에 저장하는데 그 형식이 공 개되지 않아 별도의 외부 소프트웨어를 활용하여 $\mathrm{cmd}$ 파 일을 ASCII(American Standard Code for Information Interchange) 파일 형태로 변환하고, 그 결과를 신규 개발한 분석 소프트웨어에서 활용하여야 하는 불편함이 있었다. 또한 이 러한 ASCII 파일에 표시하는 심볼의 색상, 크기, 모양이 지 정되어 있어 사용자가 원하는 형태로 결과를 분석하기가 거의 불가능하였다. Romes는 측정 결과를 관리하기 위한 데이터베이스를 지원하지 않아 방대한 분량의 이동 측정 데이터 관리에 문제가 있었으며, TII(Transmitter Identification Information)와 CIR(Channel Impulse Response) 측정 을 지원하지 않아 SFN 환경에서 적용하기에 문제가 있었 다. 또한 T-DMB 비디오 서비스에 대한 측정을 지원하지 않아 비디오 서비스의 커버리지 측정이 불가능 하다는 문 제가 있었다.

UMODIR은 전계강도 측정기, $\mathrm{DAB}$ 기준 수신기, GPS 수신기, 오실로스코프, 측정 소프트웨어, 분석 소프트웨어 로 구성되어 있으며, 전계강도, $\mathrm{DAB}$ 오디오 수신 품질 뿐 만 아니라 $\mathrm{CIR}, \mathrm{TII}$ 측정을 지원하여 $\mathrm{SFN}$ 환경에서 적용 가능하며, 데이터베이스를 지원하므로 측정 결과를 효율적 으로 관리할 수 있는 장점이 있었다 ${ }^{[8]}$. 그러나 UMODIR에 서 지원하는 분석 소프트웨어에서는 국내의 전자지도 활용 이 쉽지 않아 결과 분석을 위한 소프트웨어를 별도로 개발 해야 하는 불편함이 있었으며, 오실로스코프를 이용한 CIR 측정은 별도의 응용 소프트웨어에서 수행되어 다른 항목의 측정 결과와 연계가 섭지 않은 문제가 있었다. 측정차에서
이동 측정을 수행한 결과를 실내의 분석 시스템으로 이동 하여 결과 분석을 하고자 하는 경우에도 측정 결과의 추출 이 쉽지 않았고, 이도 특정 측정 항목으로만 제약이 되어있 는 문제가 있었다. 또한 전송 오류에 취약한 TII 측정 결과 를 기준 수신기에서 제공하는 값을 그대로 수신하므로 실 제 존재하지 않은 송신기에 대한 TII 측정 결과를 제공하거 나 실제 측정 지점의 수신 신호에 기여하지만 신호 세기가 기준값 이하인 송신기에 대한 TII 촉정 결과를 제공하지 않 는 경우가 발생하여 TII 측정 결과의 정확성이 낮았고, $\mathrm{T}-\mathrm{DMB}$ 비디오 서비스에 대한 측정을 지원하지 않는 문제 가 있었다.

저자가 이전 논문에서 제안한 통합 이동 측정 시스템은 T-DMB에서의 비트 오류율과 전계강도 측정을 목적으로 개발되었으며, 2003년과 2004년에 정보 통신부의 '지상파 $\mathrm{DMB}$ 동영상 실험방송’ 국책 과제에 이동 측정 시스템으로 활용되었다 ${ }^{[9[10]}$. 그러나 이를 SFN 환경에서 적용하기 위해 서는 $\mathrm{TII}$ 와 $\mathrm{CIR}$ 측정을 필요로 하였고, 방대한 이동 측정 데이터를 관리하기 위한 데이터베이스 지원과 전자지도를 이용한 측정 결과 분석 기능이 필요하였다. 또한 T-DMB 비디오 서비스의 수신 품질에 대한 측정을 필요로 하였다.

\section{T-DMB 측정 시스템을 위한 요구사항}

기존 측정 시스템의 문제점을 해결하고, $\mathrm{SFN}$ 구성, 커버리 지 산출, 음영 지역 해소를 지원하기 위한 새로운 T-DMB 측 정 시스템에 대한 요구 사항을 다음과 같이 도출하였다(표 1).

\section{$\mathrm{IV} . \mathrm{T}-\mathrm{DMB}$ 를 위한 통합 측정 및 분석 시스템}

본 논문에서는 <표 1>의 요구 사항을 기반으로 새로운 측정 시스템인 T-DMB IMAS(T-DMB Integrated Measurement and Analysis System)를 제안하였다(그림 1). 제안한 시스템은 독립적인 기능 모듈을 담당하는 커버리지 측정 시 스템, 멀터 측정 시스템, 비디오 측정 시스템, 분석 시스템, 재생 시스템으로 구성되었으며, Windows2000, WindowsXP 
표 1. T-DMB 측정 시스템을 위한 요구 사항

Table 1. Requirements for T-DMB Measurement System

\begin{tabular}{|c|c|}
\hline \multirow{7}{*}{ 측정 } & $\begin{array}{l}\text { 측정 항목 } \\
\text { - SFN 툭성을 고려한 측정 항목 (TII, CIR 등) } \\
\text { - 다각적인 수신품질 분석이 가능한 다양한 항목 }\end{array}$ \\
\hline & 이동, 고정, 휴대 측정 \\
\hline & 측정 과정 자동화 \\
\hline & - 사용의 편의성 \\
\hline & - 사용자의 조작 실수로 발생하는 측정 결과 정확성 저하 방지 \\
\hline & 리소스를 절약하기 위한 다수 채널 동시 측정 \\
\hline & T-DMB 비디오 서비스 수신품질 측정 (주관적, 객관적) \\
\hline \multirow{2}{*}{ 분석 } & 측정결과 전자지도 도시 \\
\hline & 전자지도를 이용한 $2 \mathrm{D}, 3 \mathrm{D}$ 지리 정보 제공 \\
\hline 재생 & 다각적 분석을 위한 측정결과 재생 \\
\hline 데이터 관리 & 방대한 측정 데이터 관리에 효율적인 시스템 구조와 데이터베이스 \\
\hline
\end{tabular}

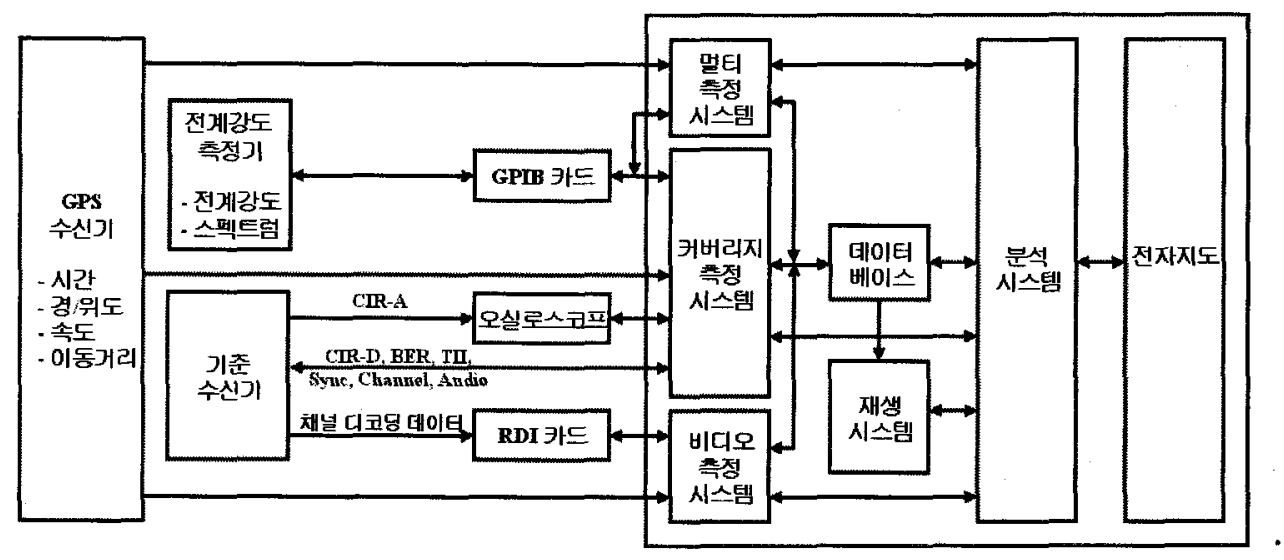

그림 1. T-DMB IMAS 블록도

Fig. 1. Block Diagram of T-DMB IMAS

의 OS 환경에서 Delphi 6.0과 Visual C+ 6.0 을 이용하여 개발하였다. 데이터베이스에는 $\mathrm{MySql}$ 을 사용하였고, 계측 기와의 연결은 RS-232(Recommended Standard-232), GPIB (General Purpose Interface Bus)(IEEE 488.2), TCP/IP(Transmission Control Protocol / Internet Protocol), USB(Universal Serial Bus), RDI(Receiver Data Interface) 등의 인터페이스 를 사용하였다 ${ }^{[1]}$.

전계강도 측정기로는 Rohde Schwarz사의 ESPI를 사용 하며, 채널파워, 전계강도, $\mathrm{RF}$ 스펙트럼을 측정한다. 기준
수신기로는 Philips사의 DAB752를 사용하며, 수신 신호에 누적된 FIC(Fast Information Channel), MSC(Main Service Channel), 오디오 서비스에 대한 오류 정보를 측정하고, 아 날로그 CIR 촉정에 필요한 CIR과 Trigger 신호를 제공한다. 또한 시간 디인터리빙(Time Deinterleaving)과 비터비 디코 딩(Viterbi Decoding)이 완료된 서브 채널 데이터를 RDI 출 력을 통해 제공하여 비디오 측정 시스템에서 이용할 수 있 도록 지원한다. 오실로스코프(Oscilloscope)로는 National Instrument사의 NI Scope를 사용하며, DAB752의 CIR과 
Trigger 신호를 이용하여 아날로그 $\mathrm{CRR}$ 을 측정한다. 메인시 스템은 윈도우 OS 기반의 범용 $\mathrm{PC}$ 을 사용하며, 데이터베이 스 생성과 관리, 계측기 제어, 측정 결과 및 시스템 오류 관 리 등을 수행한다.

\section{1. 커버리지 측정 시스템}

커버리지 측정 시스템은 T-DMB 방송망 구축과 수신 품 질 측정을 수행한다. 이를 위해 측정에 필요한 데이터베이 스를 생성 및 관리하고, 계측기로부터 측정값을 수집하고 통합하여 데이터베이스에 저장한다. 관련된 데이터베이스 에는 송/중계소 정보를 관리하는 송/중계소 DB, T-DMB 서 비스 정보를 관리하는 서비스 $\mathrm{DB}$, 계측기 설정 정보를 관 리하는 장비 설정 $\mathrm{DB}$, 수신 안테나 정보를 관리하는 안테 $4 \mathrm{DB}$, 측정 결과를 전자지도에 도시하기 위한 범례 $\mathrm{DB}$, 측정중 발생한 시스템 오류를 관리하는 오류 로그 $\mathrm{DB}$, 측 정 결과를 저장 및 관리하는 측정 결과 $\mathrm{DB}$ 가 있다.

측정을 시작하기 전에 커버리지 측정 시스템은 각각의 계측기와 통신 상태를 점검한다. 점검 결과 이상이 없으면 장비 설정 $\mathrm{DB}$ 에서 개별 계측기에 설정할 값을 읽고, 이를 계측기에 전달한다. 계측기에 설정이 완료되면 전자지도를 로덩하고, 측정에 이용되는 다른 $\mathrm{DB}$ 들의 상태를 점검한다. 측정을 시작하면 계측기 제어, 전자지도 실행, 측정 결과 통 합 저장, 사용자 메모 입력, 시스템 오류 관리 등을 담당하 는 스레드가 순차적으로 구동된다. 정상적으로 측정이 진행 되면 개별 장비에서 측정한 결과를 주기적으로 수집하여
사용자 메모 입력과 함께 측정 결과 $\mathrm{DB}$ 에 기록한다. 일정 한 시간이 경과한 이후에도 장비에서 응답이 없으면 재요 청 명령을 보내고, 계속 응답이 없으면 시스템 오류를 기록 하고 측정을 중지한다.

본 시스템의 측정 항목은 <표 2>와 같다. 주요한 항목으 로는 전계강도, $\mathrm{TII}, \mathrm{CIR}$ 이 있다 [3]14][5] $^{2}$.

전계강도는 수신가능 여부를 판단하여 커버리지를 산출 하기 위한 목적으로 주로 사용되며, 유효 전계강도 레벨 이 상을 확보한 지역은 커버리지로 분류된다. 유효 전계강도 레벨 이상인 지역도 수신이 불가능한 경우가 있는데 그 원 인으로는 ETS 300 799의 조건에 어긋난 잘못된 SFN 구성, 보호 구간을 벗어난 다중 경로 신호와 원거리 송신기 신호 의 간섭, 중계기의 잘못된 사용으로 인한 신호 지연, 인접 및 동일 채널 간섭 등이 있다.

TII는 SFN 형태로 구성된 T-DMB 방송망에서 개별 송신 기를 식별하는 정보로 사용되며, $96 \mathrm{~ms}$ 길이를 갖는 $\mathrm{DMB}$ 전송 프레임의 널 심볼(Null Symbol)에 삽입되어 전송된다. 수신 신호가 복수의 TII를 포함하는 경우에도 개별 TII에 대한 복원이 가능하므로 TII는 수신 신호를 구성하는 송신 기에 대한 정보를 제공할 수 있다. TI는 채널 부호화, 시간 및 주파수 인터리빙이 적용되지 않기 때문에 전송 오류와 다중 경로 페이딩에 취약하고, 그 결과 실제 존재하지 않은 송신기에 대한 TII 측정 결과를 제공하거나 실제 수신 신호 를 구성하지만 신호 세기가 기준값 이하인 송신기에 대한 TII 측정 결과를 제공하지 않는 경우가 발생한다. 기존 시스 템에서는 TII 측정에 이러한 특성을 고려하지 않고 기준 수

표 2. 커버리지 측정 시스템의 측정항목

Table 2. Measured Parameters of Coverage Measurement System

\begin{tabular}{|c|l|}
\hline 전계강도 & $\mathrm{RF}$ 스펙트럼, 채널파워 $(\mathrm{dBm})$, 전계강도 (dBuV/m) \\
\hline TII (반복) & 관심 TIls, 수신 Tlls, Main Id, Sub Id, 신호세기, 송신소명, 송신소 거리 \\
\hline $\mathrm{CIR}$ & $\begin{array}{l}\text { 아날로그 CIR, 첫 번째 피크, 평균 피크, 마지막 피크, 첫 번째 피크와 마지막 피크의 } \\
\text { 시간차 및 거리차 }\end{array}$ \\
\hline Sync & 널 심볼, 시간, 주파수, 채널, 오디오 \\
\hline Audio & 묵음 처리된 프레임 수, 동기 오류 프레임 수, ISO CRC 오류 수, 스케일 팩터 오류 수 \\
\hline Subchannel & FIC의 오류 비트 수, FIB의 오류 블록 수, $\mathrm{MSC}$ 의 오류 비트 수 \\
\hline GPS & 시간, 속도, 거리, 경도, 위도 \\
\hline 사용자 입력 & 주관적 수신 품질, 지리 정보, 사용자 임의 정보 \\
\hline
\end{tabular}


신기에서 제공하는 $\mathrm{TII}$ 측정 결과를 그대로 수신하므로 측 정 결과의 정확성이 낮은 문제가 있었다. 그러나 제안한 시 스템에서는 측정 지점을 기준으로 등록한 관심 송/중계소 리스트의 범위 내에 존재하는 송신기의 TI를 기준 수신기 에 주기적으로 전송하고 이를 이용하여 기준 수신기가 해 당 송신기 신호의 존재 여부와 신호 세기 등에 관한 정보를 측정하는 방식을 적용하여 TII 측정 결과의 정확성을 향상 하였다.

CIR은 수신 신호에 포함된 송/중계기의 신호와 다중 경 로 신호의 시간 분포 정보를 제공하며, 다수의 피크들로 구 성된다. CIR을 이용하면 SFN을 구성하는 송신기들의 시간 동기 불일치, 원거리 송신기 신호의 간섭, 중계기의 잘못된 사용 등으로 인하여 보호 구간을 벗어나는 지연 신호 존재 여부에 대하여 측정할 수 있다.

커버리지 측정 시스템의 전계강도와 CIR 측정 화면은 <그립 2>, <그림 3>과 같다.

$\mathrm{TII}$ 와 CIR 피크 사이에는 상관관계가 있다. 이러한 연관 성을 이용하면 현재 지역이 어느 송신기들의 커버리지에 위치하는지, 어떤 송신기의 신호가 보호 구간을 벗어나 위 치하는지에 대한 측정이 가능하다 ${ }^{[4]}$. TII를 이용하여 송신 기를 식별한 결과 수신 지점에서 가까운 거리에 위치한 송 신기일수록 CIR 그래프에서 시간축 상에서 앞서 위치하는 피크를 구성한다. 또한 수신된 TII 신호 세기가 큰 송신기일 수록 CIR 그래프에서 신호의 크기가 큰 피크를 구성한다. 제안한 시스템에서는 TI와 CIR의 상관관계 분석을 용이하

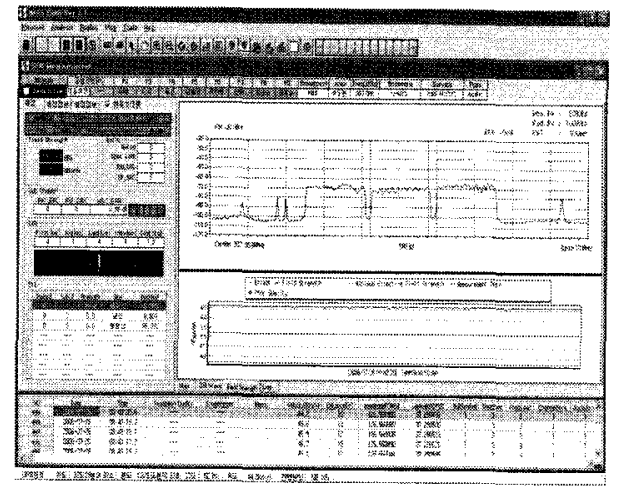

그림 2. 전계강도

Fig. 2. Field Strength

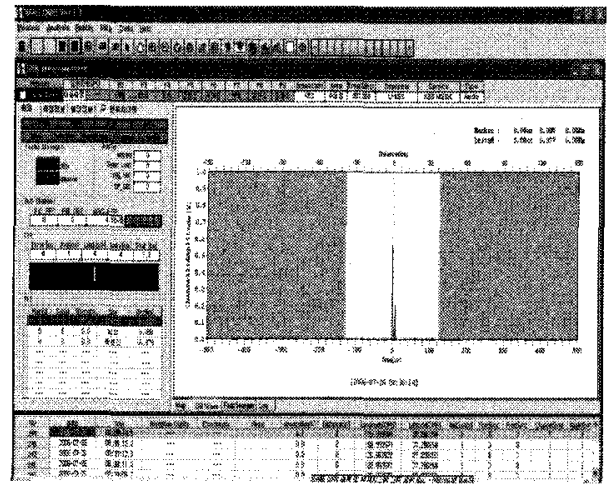

그림 3. CIR

Fig. 3. CIR

게 하기 위한 방법을 지원한다. 여기에는 수신점을 기준으 로 한 송신소의 방향과 거리의 전자지도 도시, TII 측정 결 과를 기준으로 측정된 송신소 리스트를 신호 세기 및 거리 순서로 정렬, CIR 그래프에서 마커를 이용한 시간-거리 자 동 환산 제공, CIR 그래프의 시간축 해상도 변경 등이 있다.

본 시스템에서는 선택한 측정 항목에 대하여 측정과 동 시에 측정 결과값에 따라 다른 색상의 심볼을 할당하여 전 자지도에 도시하는 기능을 지원한다. 이러한 방식으로 측정 데이터에 대한 시각적인 히스토리 정보를 제공함으로써 지 리적인 특성에 따른 수신 품질의 실시간 분석이 가능하다. <그림 4>는 TII 측정결과 신호가 가장 큰 송신소를 추출하 여 이를 기준으로 수신점 위치에서의 주 송신기를 지도상 의 이동 측정 경로를 따라 도시한 것이다.

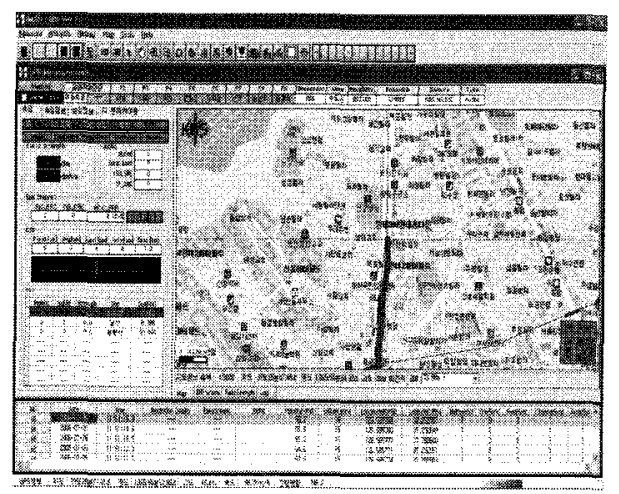

그림 4. 주 송신기에 대한 시각적 히스토리

Fig. 4. Visual History about a Main Transmitter 


\section{2. 멀티 측정 시스템}

본 논문에서는 측정 리소스를 절약하기 위한 방법으로 멀티 측정 시스템을 제안한다. 멀티 측정 시스템은 다수의 T-DMB 채널에 대한 전계강도와 스펙트럼의 동시 측정을 지원하므로 예산, 시간, 인력 등의 측정 리소스를 절약할 수 있다. 이러한 이유로 실제 펼드 테스트에서도 가장 많이 적 용되었다. 본 시스템은 T-DMB 외에도 NTSC, PAL, ATSC, DVB-T, FM, AM, DRM 등의 다른 방송 방식에도 적용 가 능하도록 개발되었다. 1 회의 측정에서 최대 6 개의 독립된 $\mathrm{RF}$ 채널에 대한 전계강도와 스펙트럼의 동시 측정을 지원 한다(그림 5). 본 시스템의 측정 항목은 <표 3>과 같다.

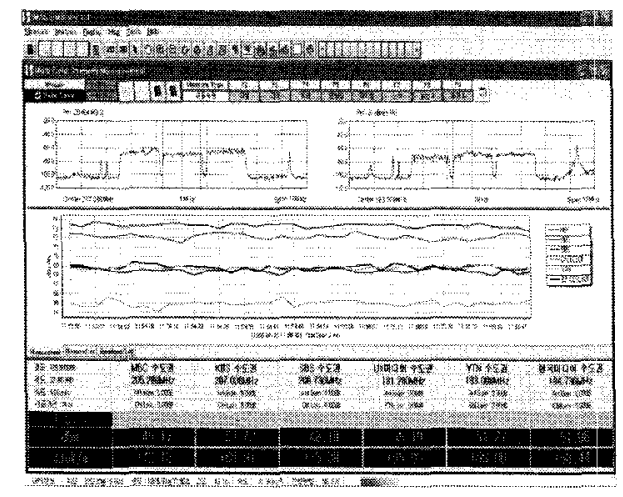

그림 5. 6개 T-DMB 채널에 대한 멀티 측정

Fig. 5. Multi Measurement about 6 T-DMB Channels

<그림 6>은 멀티 측정 과정에 대한 흐름도이다. 멀티 측 정 시스템은 측정할 채널의 주파수를 전계강도 측정기에 설정하고 주파수 변경 여부를 장비에 확인하고, 주파수 변 경이 완료되면 전계강도 측정기가 전계강도와 스펙트럼의 측정을 진행하는 시간 동안 대기한다. 대기 시간 경과 후에
장비에 측정 완료 여부를 확인하고, 측정 데이터를 요청한 다. 현재 채널 측정이 완료되면 다른 채널로 변환하여 동일 과정을 반복한다.

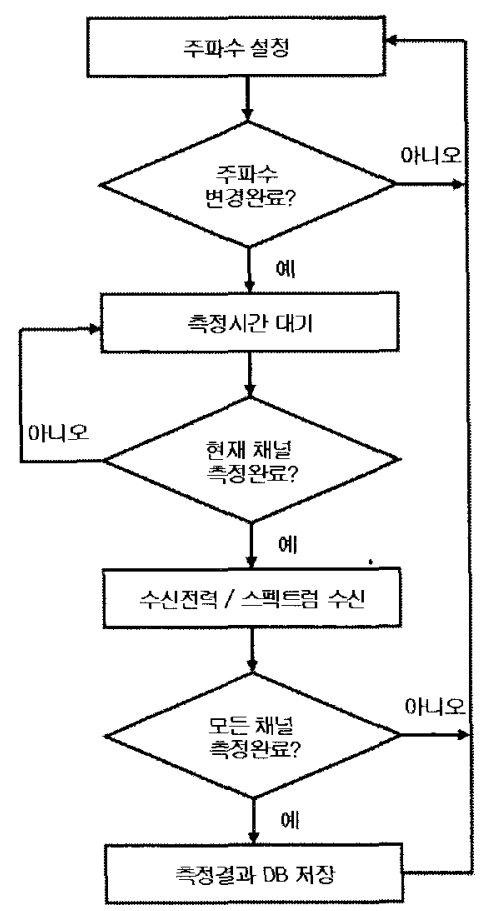

그림 6. 멀티 측정 과정 흐름도

Fig. 6. Flow Chart of Multi Measurement Process

\section{3. 비디오 측정 시스템}

본 논문에서는 이동 중에 T-DMB 비디오 서비스의 수신 품질을 측정하기 위한 비디오 측정 시스템을 제안한다. 비 디오 측정 시스템은 기준 수신기에서 채널 디코딩(시간 디 인터리빙, 비터비 디코딩)이 완료된 비디오 스트림을 RDI

표 3. 멀티 측정 시스템의 측정항목

Table 3. Measured Parameters of Multi Measurement System

\begin{tabular}{|c|l|}
\hline $\begin{array}{c}\text { 전계강도 } \\
\text { (6개 채널) }\end{array}$ & $\mathrm{RF}$ 스펙트럼, 채널파워 $(\mathrm{dBm})$, 전계강도 $(\mathrm{dBuV} / \mathrm{m})$ \\
\hline $\mathrm{GPS}$ & 시간, 속도, 거리, 경도, 위도 \\
\hline 사용자 입력 & 주관적 수신 품질, 지리 정보, 사용자 임의 정보 \\
\hline
\end{tabular}




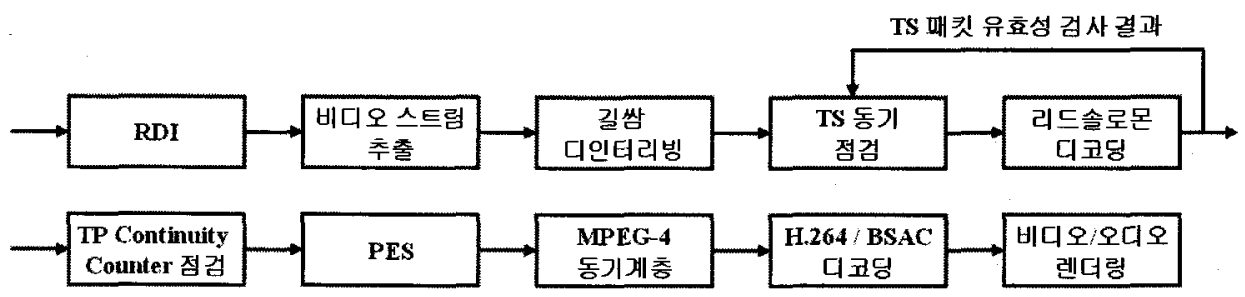

그림 7. 비디오 측정 시스템을 위한 절차

Fig. 7. Procedure for Video Measurement System

를 통해 실시간으로 수신하고, <그림 7>의 절차에 따라 관 련된 오류 정보들을 계산한다. 또한 수신된 비디오 스트림 을 저장하고, 이를 측정 결과와 연계하기 위한 링크 파일을 생성하여 저장한다.

주관적인 화질 평가를 지원하기 위해 비디오 프레임을 렌더링하는 2가지 방식을 지원하는데, 여기에는 오류 $\mathrm{P}$ 프 레임부터 정상 I 프레임까지 오류가 전파되는 구간을 렌더 링에서 제외하는 방식과 오류 전파 구간의 비디오 프레임
들에 대한 렌더링을 수행하는 방식이 있다. 첫 번째 렌더링 방식에서 오류 구간의 비디오는 프레임 정지 형태(Frame Freezing)로 표현된다. 두 번째 렌더링 방식에서는 오류 구 간의 비디오는 인접 프레임들에서 오류가 확산(Error Propagation)되는 형태로 재생되며, 이는 주관적 화질 평가에 유용하게 활용된다.

본 시스템의 측정 항목은 <표 $4>$ 와 같다. 수신 품질과 관련하여 중요한 항목으로는 '리드솔로몬 디코딩(Reed

표 4. 비디오 측정 시스템의 측정항목

Table 4. Measured Parameters of Video Measurement System

\begin{tabular}{|c|c|c|}
\hline \multicolumn{2}{|c|}{ Sync } & RDI, TS 패킷 \\
\hline \multicolumn{2}{|c|}{ TS 패킷 } & $\begin{array}{l}\text { 예측 패킷 수, 수신 패킷 수, 유실 패킷 수, 동기 오류 패킷 수, 오류 패킷 수, 오류 정정 } \\
\text { 패킷 수, 정상 패킷 수, Continuity Counter 오류 패킷 수, RS 디코딩 전단 패킷 오류율, } \\
\text { RS 디코딩 후단 패킷 오류율 }\end{array}$ \\
\hline \multicolumn{2}{|c|}{ PES } & 수신 비디오 PES 수, 오류 비디오 PES 수, 수신 오디오 PES 수, 오류 오디오 PES 수 \\
\hline \multicolumn{2}{|c|}{ 프레임 } & $\begin{array}{l}\text { 예측 비디오 프레임 수, 수신 비디오 프레임 수, 유실 비디오 프레임 수, 오류 비디오 } \\
\text { 프레임 수, 정상 비디오 프레임 수, 비디오 프레임 오류율, 예측 오디오 프레임 수, 수신 } \\
\text { 오디오 프레임 수, 유실 오디오 프레임 수, 오류 오디오 프레임 수, 정상 오디오 프레임 } \\
\text { 수, 오디오 프레임 오류율 }\end{array}$ \\
\hline \multirow{4}{*}{ PSI } & PAT & 최대 간격, 수신 PAT 수, 유효 PAT 수 \\
\hline & PMT & 최대 간격, 수신 PMT 수, 유효 PMT 수 \\
\hline & OD & 최대 간격, 수신 OD 수, 유효 OD 수 \\
\hline & BIFS & 최대 간격, 수신 BIFS 수, 유효 BIFS 수 \\
\hline \multirow{4}{*}{ Clock } & PCR & 최대 간격, 수신 PCR 수, 유효 PCR 수 \\
\hline & OCR & 최대 간격, 수신 OCR 수, 유효 OCR 수 \\
\hline & CTS & 최대 간격, 수신 CTS 수, 유효 CTS 수 \\
\hline & PTS & 최대 간격, 수신 PTS 수, 유효 PTS 수 \\
\hline \multicolumn{2}{|c|}{ 비트율 } & 전체, 비디오, 오디오, 데이터, PAT, PMT, OD, BIFS, 널 TS 패킷 \\
\hline \multicolumn{2}{|c|}{ GPS } & 시간, 속도, 거리, 경도, 위도 \\
\hline \multicolumn{2}{|c|}{ 렌더링 } & 초당 렌더링 된 프레임 수, 1 프레임 간격 \\
\hline \multicolumn{2}{|c|}{ 사용자 입력 } & 주관적 수신품질, 지리 정보, 사용자 임의 정보 \\
\hline
\end{tabular}


Solomon Decoding) 전단의 TS(Transport Stream) 패킷 오류 율'과 ‘리드솔로몬 디코딩 후단의 TS 패킷의 오류율', '비 디오 프래임 오류율'이 있다. '리드솔로몬 디코딩 전단의 TS 패킷 오류율'은 DAB 레벨의 내부호화에 대한 디코딩 (시간 디인터리빙, 비터비 디코딩)이 적용된 이후에 수신 TS 패킷 수에서 오류 TS 패킷 수가 차지하는 비율을, '리드 솔로몬 디코딩 후단의 TS 패킷 오류율'은 외부호화에 대한 디코딩(길쌈 디인터리빙, 리드솔로몬 디코딩) 이후에 수신 TS 패킷 수에서 오류 TS 패킷 수가 차지하는 비율을 나타 낸다. '비디오 프레임 오류율'은 ‘수신 비디오 프레임 수'에 서 '오류 비디오 프레임 수'에 대한 비율을 나타낸다.

송수신 과정에서 전송 오류가 존재하면 일부 전송 데이 터가 유실되어 송신 데이터 개수와 수신 데이터 개수에 차 이가 발생할 수 있다. 전송 오류가 증가하면 유실된 데이터 개수도 증가하며, 이를 오류율 계산에 반영하지 않으면 측 정결과가 부정확하게 된다. 이러한 문제를 해결하기 위하여 본 논문에서는 수신이 예측되는 데이터 개수와 유실된 데 이터 개수를 산출하는 알고리즘을 제안한다.

'예측 TP(Transport Stream Packet) 수'를 산출하는 방법 은 <그림 8>과 같다. 이동 측정 간격(또는 측정 주기, Measurement Interval) 동안 TP에 오류가 발생하지 않는다 면 유실된 TP가 없으므로 '예측 TP 수'는 '수신 TP 수'와 일치한다. 측정 간격 동안 $\mathrm{TP}$ 에 오류가 발생하였다면 해당 시간 동안 TP 오류가 발생하지 않은 PCR(Program Clock Reference) 구간이 존재하는지 확인하고, 존재한다면 그 구 간의 TP 수를 카운트한다. 이렇게 얻어진 PCR 구간 동안의 $\mathrm{TP}$ 수를 측정간격 동안의 $\mathrm{TP}$ 수로 환산하여 '예측 $\mathrm{TP}$ 수’를 산출한다(그림 9, 수식 1). 수식 (1)에서 PCR(a)와 PCR(b)는
$\mathrm{TP}$ 오류가 발생하지 않은 $\mathrm{PCR}$ 구간의 $\mathrm{PCR}$ 값을, $\mathrm{PCR}$ 구간 의 $\mathrm{TP}$ 수는 $\mathrm{PCR}(\mathrm{a})$ 와 $\mathrm{PCR}(\mathrm{b})$ 사이에 전송된 총 $\mathrm{TP}$ 수를 나 타낸다. PCR은 인코더와 디코더의 시스탬 타임을 일치시키 기 위한 목적으로 사용되며, 인코더에서 $27 \mathrm{MHz}$ 의 시스템 클록을 기준으로 생성하여 전송하기 때문에 두 PCR 사이 의 총 비트 수는 해당 구간의 총 비트율과 동일하게 이용된 다. 그러므로 이를 이용하면 정확한 '예측 TP 수' 산출이 가능하다. 측정 간격 동안 TP 오류가 발생하지 않은 PCR 구간이 없었다면 가장 최근의 정상 $\mathrm{PCR}$ 구간을 이용하고, 측정 시작 이후예 정상 $\mathrm{PCR}$ 구간이 한 번도 없었다면 비디 오 서비스의 총 비트율과 측정 간격을 곱한 결과를 204바이 트 단위로 환산하여 '예측 $\mathrm{TP}$ 수’를 계산한다.

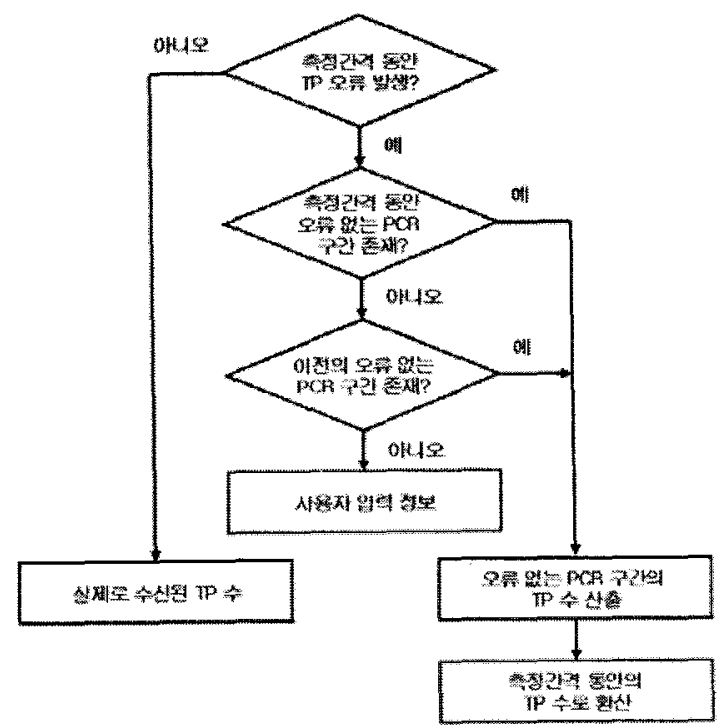

그림 8. 예측 TP 수 산출 흐룜도

Fig. 8. Flow Chart for Calculating The Number of Expected TP

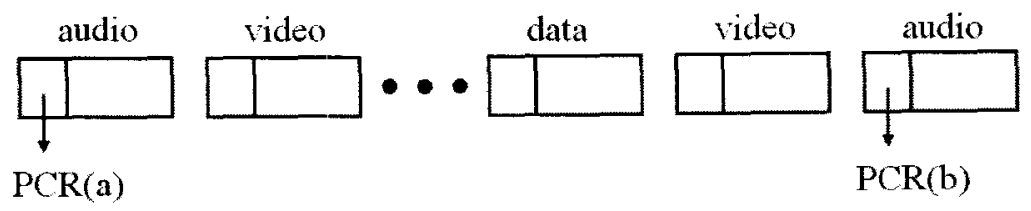

그림 9. PCR 구간의 TS

Fig. 9. Transport Stream within PCR Interval

$$
\text { 예측 } T P \text { 수 }=\frac{\text { Sustem ClockFrequency }}{P C R(b)-P C R(a)} \times P C R \text { 구간의 } T P \text { 수 } \times \text { 측정간격 }
$$




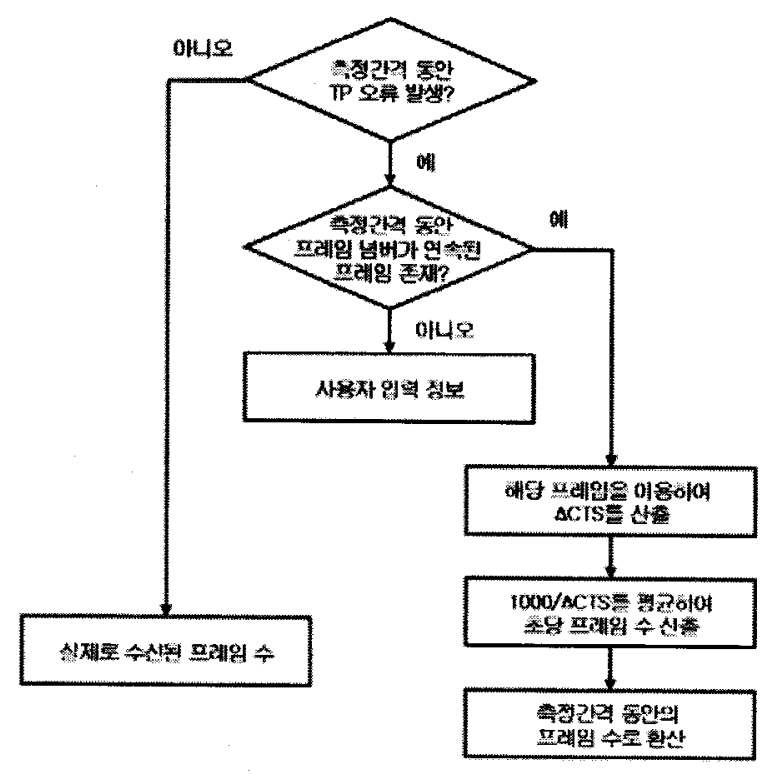

그림 10. 예측 비디오 프레임 수 산출 흐름도

Fig. 10. Flow Chart for Calculating The Number of Expected Video Frame

'예측 비디오 프레임 수'를 계산하기 위한 방법은<그 림 $10>$ 과 같다. 측정 간격 동안 TP에 오류가 발생하지 않 았다면 유실된 데이터가 없는 경우이므로 '예측 비디오 프레임 수'는 '실제 수신된 비디오 프레임 수'와 일치한 다. 측정 간격 동안 $\mathrm{TP}$ 에 오류가 발생하였다면 '예측 비디 오 프레임 수'를 산출하기 위해 비디오 프레임 넘버가 연 속된 프레임이 존재하는지 확인하고, 해당 프레임 사이의 CTS(Composition Time Stamp) 차이인 $\triangle \mathrm{CTS}$ 를 산출하여 그 역수와 1000 을 곱한 결과를 계산한다. 프레임 넘버는 인 코더 단에서 비디오 프레임마다 할당한 값으로 GOP(Group Of Picture) 내에서 연속된 프레임마다 1 씩 증가한다. 측정 간격 동안의 모든 연속된 비디오 프레임들에 대하여 해당 연산을 반복하고, 계산 결과를 평균하여 초당 예측 프레임 수를 산출한다. 산출된 결과를 측정 간격으로 환산하면 예
측 비디오 프레임 수가 산출된다(그림 11, 수식 2). <그림 $11>$ 의 경우 프레임 넘버가 3 과 6 인 프레임은 오류 프레임 으로 $\triangle \mathrm{CTS}$ 산출 과정에서 제외된다. 프레임 넘버가 연 속된 프레임이 존재하지 않으면 서비스 정보 $\mathrm{DB}$ 에서 측 정 중인 비디오 서비스에 대한 초당 비디오 프레임 수를 참조하고, 이를 측정 간격으로 환산하여 예측 비디오 프 레임 수를 계산한다. ES(Elementary Stream)의 동기화 된 재생을 위한 타임 스탬프는 SL(Sync Layer) Config Descriptor에 존재하는 useTimeStampsFlag 값에 따라 CTS 형태로 SL(Sync Layer) 패킷 헤더에서 전송될 수도 있고, SL Config Descriptor에 설정 가능한 시간 정보 (timeScale, accessUnitDuration, compositionUnitDuration, startDecodingTimeStamp, startCompositionTimeStamp)에 의해 전송 될 수도 있다. 지상파 $\mathrm{DMB}$ 비디오 송수신 정합 표준에서는 useTimeStampsFlag를 1로 고정하여 CTS 형태의 시간 동기 정보의 사용을 규정하고 있고, 본 논문에서 제안한 '예측 비디오 프레임 수'를 산출하는 알고리즘에는 이러한 사항 이 전제되었다 ${ }^{[1][12]}$.

‘예측 오디오 프레임 수'를 계산하기 위한 방법은 $\triangle \mathrm{CTS}$ 를 산출하기 위한 연속된 오디오 프레임을 결정하는 기준 이 오디오 TP의 Continuity Counter를 이용한다는 사실을 제외하면 '예측 비디오 프레임 수'를 결정하는 방법과 동일 하다.

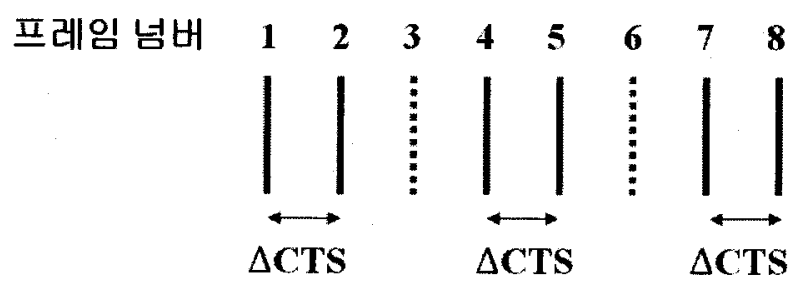

그림 11. 비디오 프레임 시퀀스와 $\triangle \mathrm{CTS}$ 정의

Fig. 11. Sequence of Video Frames and Definition of $\triangle \mathrm{CTS}$

$$
\text { 예측비디오프레임수 }=\frac{\sum_{i} \frac{1000}{\triangle C T S_{i}}}{\sum_{i} i} \times \text { 측정간격 }
$$


비디오 측정 시스템의 측정 과정과 실시간 그래프는<그 림 $12>$, <그림 $13>$ 과 같다.

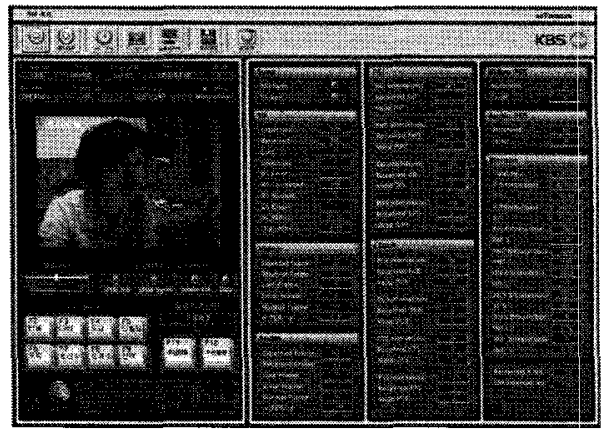

그림 12. 비디오 측정 시스템의 측정 과정

Fig. 12. Measurement Process of Video Measurement System

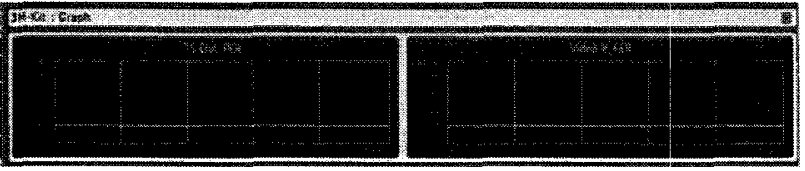

그림 13. RS 디코딩 후단 TS 패킷 오류율과 비디오 프레임 오류율 그래프 Fig. 13. Graph of Error Rate in TS Packets after RS Decoding and Video Frames

\section{4. 분석 시스템}

분석 시스템은 이동 측정 결과의 전자지도 도시, 측정 지
점에 대한 지리 정보 분석 및 수신율 산출을 위한 목적으로 사용된다.

측정 결과는 전자지도에 도시하기 이전에 데이터베이스 에서 호출하여 필터링, 수정, 삭제, 평균 등과 같은 가공이 가능하다(그림 $14-\mathrm{a}, \mathrm{b}$ ). 가공이 완료된 데이터는 범용 텍 스트 파일 포맷인 CSV(Comma Separated Value) 파일로 저 장되며, 전자지도를 실행하여 $\mathrm{CSV}$ 파일을 로딩하면 도시 가 완료된다. 그림 $15>$ 은 이동 측정 경로에 따라 전계강도 와 $\mathrm{TII}$ 의 신호세기에 의해 결정된 주 송신기를 전자지도 상 에 도시한 것이다. 그림 $15-\mathrm{a}, \mathrm{b}>$ 는 전계강도 세기에 따라 구간별로 색상을 구분하여 도시한 결과로 파란색 샘플에 가까울수록 수신이 양호한 측정지점이다. <그림 $15-\mathrm{c}, \mathrm{d}>$ 는 이동측정 결과 TI의 신호 세기가 가장 큰 송신소를 전자 지도에 도시한 것으로 빨간색 샘풀은 관악산, 파란색 샘풀 은 남산, 노란색 샘플은 용문산 신호에 의해 주로 영향을 받는 지점을 나타낸다.

제안한 시스템은 측정 결과의 정확한 분석을 위해 3 가지 유형의 지리 정보를 지원한다(그림 $16-\mathrm{a}, \mathrm{b}, \mathrm{c}$ ). 여기에는 송/중계소 방향과 거리를 계산하여 그 결과를 전자지도에 도시하는 기능, 수신점이 전파의 LOS(Line Of Sight)가 확 보되는 지역인지를 확인하기 위한 지형고도 프로파일 기능, 측정 지점을 중심으로 부근의 송/중계소의 대략적인 위치 와 거리를 파악하기 위한 동심원 도시 기능이 있다. <그림

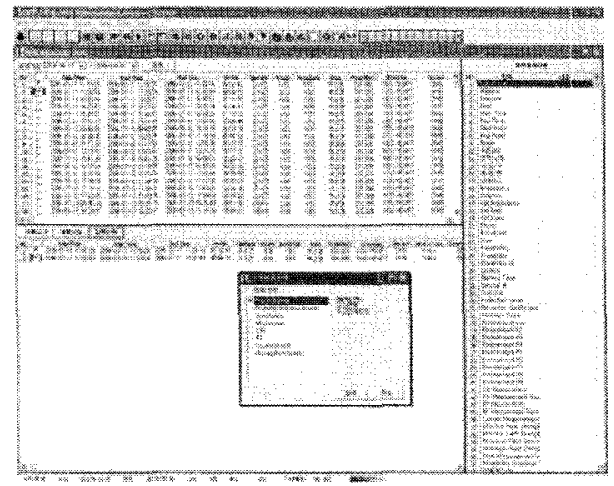

a. 측정 데이터 선택

a. Selection of Measured Data

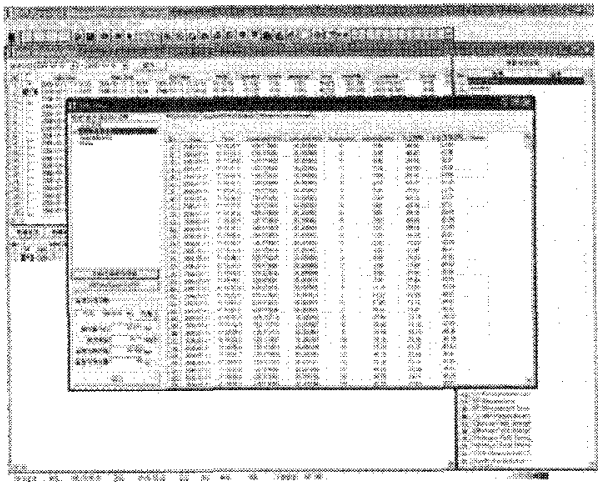

b. 분석을 위한 데이터 처리

b. Data Processing for Analysis

그림 14. 측정 결과 분석을 위한 데이터 처리

Fig. 14. Data Processing for Analyzing Measured Results 


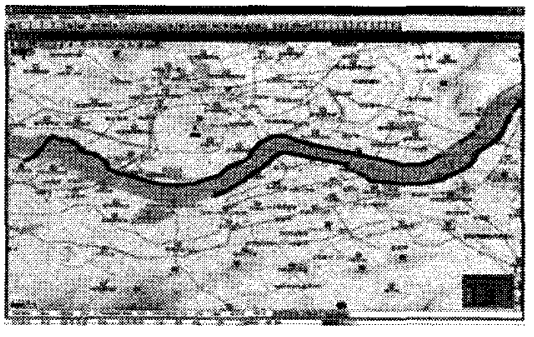

a. 전계강도

a. Field Strength

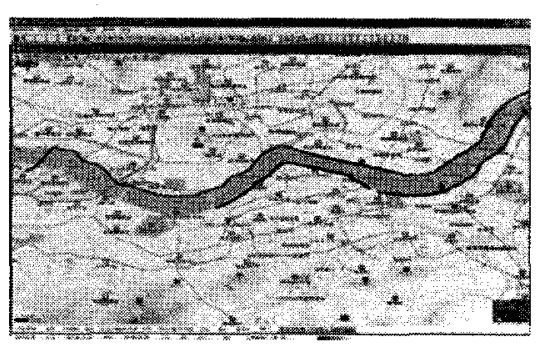

c. 주 송신기

c. A Main Transmitter

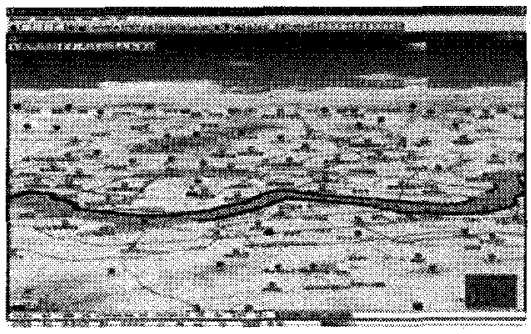

b. 전계강도 - 스카이 뷰

b. Field Strength - Sky View

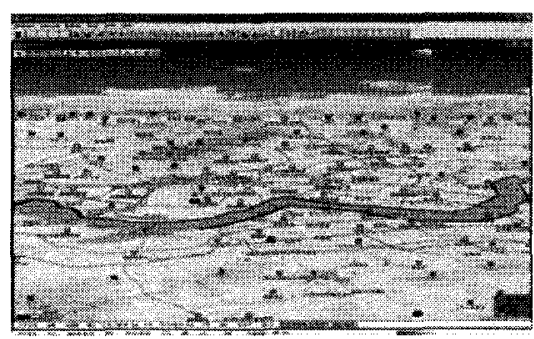

d. 주 송신기 - Sky View

d. A Main Transmitter - Sky View

그림 15. 측정 결과의 전자지도 도시

Fig. 15. Representation of Measured Data on The Electronic Map

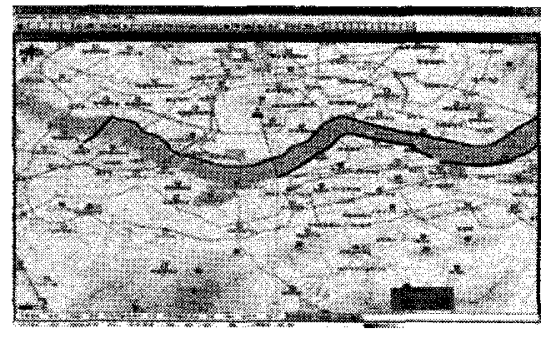

a. 송/중계소 방향과 거리

a. Distance and Direction to Transmission Sites

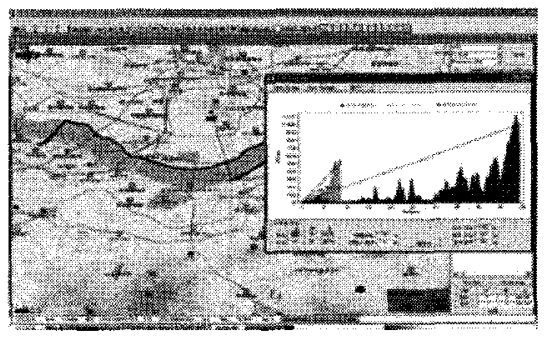

b. 송/중계소까지 고도 프로파일

b. Altitude Profile to Transmission Sites

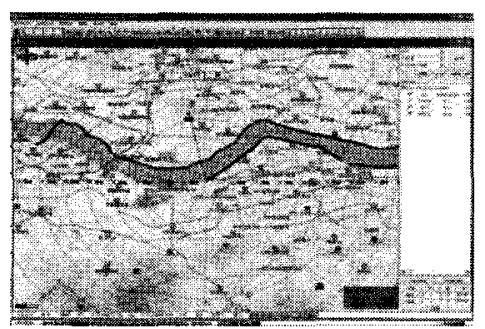
c. 동심원
c. Concentric Circles

그림 16. 분석 시스템의 지리 정보

Fig. 16. Geographic Information of Analysis System 
$16-\mathrm{a}, \mathrm{b}, \mathrm{c}>$ 는 <그림 15-c>의 전자지도 도시 결과를 정확 하게 분석하기 위해 3 가지 유형의 지리 정보를 추가적으로 도시한 것이다.

위의 기능 이외에도 본 논문에서는 커버리지를 산출하기 위한 다른 방법으로 수신율 자동 계산을 제안한다. 수신율 은 총 이동거리, 평균 이동속도, 커버리지 거리, 수신율로 구성된다. 수신율을 산출하기 위한 커버리지 판별 기준으로 는 '전계강도', ‘리드솔로몬 디코딩 전단 TP 오류율', ‘리드 솔로몬 디코딩 후단 TP 오류율', ‘비디오 프레임 오류율’을 지원한다.

본 논문에서는 <그립 $17>$ 과 같이 이동 측정 결과 발생 한 방대한 분량의 데이터 관리 및 처리에 효율적인 측정 및 분석 환경을 제안한다. 사용자에 의해 선택된 측정 데 이터는 파일과 데이터베이스 형태로 추출이 가능하다. 추출된 데이터는 외부 저장 장치 또는 TCP/IP 네트워크 를 통해 분석 시스템으로 이동하여 관리와 분석이 가능 하다. 송/중계소 $\mathrm{DB}$, 서비스 정보 $\mathrm{DB}$, 채널 정보 $\mathrm{DB}$, 장 비 설정 $\mathrm{DB}$ 등의 측정 관련 $\mathrm{DB}$ 는 반대로 분석 시스템에 서 일괄적으로 업데이트 하여 개별 측정 시스템에 적용 가능하다.

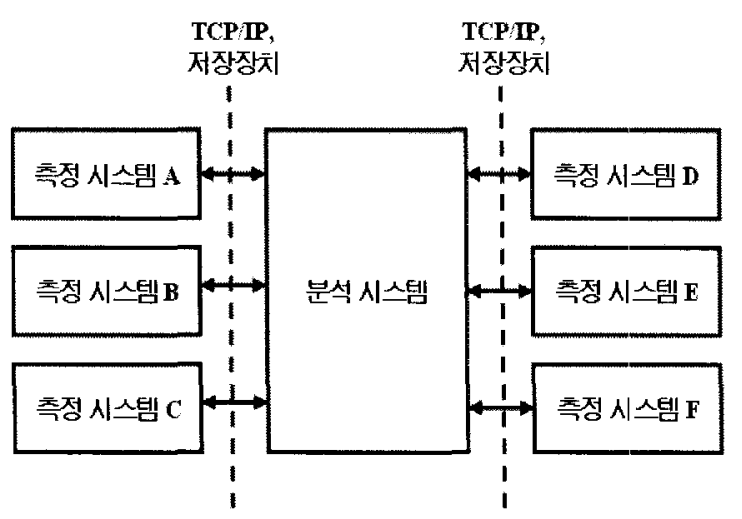

그림 17. 분산 데이터 처리

Fig. 17. Distributed Data Processing

\section{5. 재생 시스템}

본 논문에서는 측정 결과를 지리 지형 정보와 함께 다각 적으로 분석하기 위한 방법으로 재생 시스템을 제안한다.
재생 시스템은 측정이 완료된 데이터를 호출하여 측정 시 스템과 동일한 사용자 인터페이스에 재연하는 기능을 수행 한다.

기존의 측정 시스템에서는 측정 결과 중에서 1 개의 항목 을 선택하여 이를 전자지도예 도시하는 것이 결과 분석을 위한 주된 방법이었다. 결과적으로 커버리지를 산출하는 과 정에서 여러 항목들의 측정 결과를 동시에 분석하기가 쉅 지 않았으며, 이로 인하여 수신 상태가 불량한 경우에 정확 한 원인 분석이 어려웠다. 이는 방대한 측정 지점과 측정 결과를 처리해야 하는 이동 측정에서 심각한 문제가 되었 다. 재생 시스템은 이러한 문제를 해결하기 위한 목적으로 개발되었다.

사용자는 재생을 원하는 측정 결과를 선택하고 재생 과정에서 지도에 도시될 1 개의 항목을 선택한다. 현재 재 생 포인트가 전자지도 상의 위치 표시와 재생 상태 제어 다이얼로그 상의 포인터 형태로 식별된다. 현재 재생 포 인트에 해당하는 모든 측정 결과들이 데이터베이스에서 호출되어 사용자 인터페이스에 표현된다. 재생 상태 제어 다이얼로그를 조절하거나 전자지도에 도시된 특정 지점 을 선택하는 방식으로 재생 포인트 이동이 가능하다. 또 한 재생 속도 조절, 정지, 일시 정지가 지원된다. <그림 18 - a, b>와 <그림 $19-\mathrm{a}, \mathrm{b}>$ 는 커버리지 측정 시스템, 멀티 측정 시스템에 의해 측정된 결과를 재생하는 과정 을 보여준다.

비디오 측정 시스템의 측정 결과 재생 과정은 <그림 20> 과 같다. 현재 재생되고 있는 비디오 화면과 관련된 모든 측정 결과 데이터가 정확한 순간에 재연된다. 재생 포인트 를 이동하기 위한 방법으로는 현 재생 포인트 이후의 리드 솔로몬 오류가 발생한 가장 가까운 지점으로 이동, 사용자 가 슬라이더 콘트롤을 조절하는 방식을 이용한 이동, 사용 자에 의해 측정 일자와 시간을 직접 입력하는 방식의 이동 을 지원한다.

정확한 수신 품질 분석을 위해 비디오 스트림의 재생 지 점과 측정 결과의 재생 지점을 일치시키는 것이 중요하다. 이를 위하여 저장된 비디오 TS 파일과 데이터베이스의 측 정 결과를 연동하기 위한 링크 파일을 제안한다. 링크 파일 은 비디오 스트림의 시작점부터 해당 구간까지의 바이트 


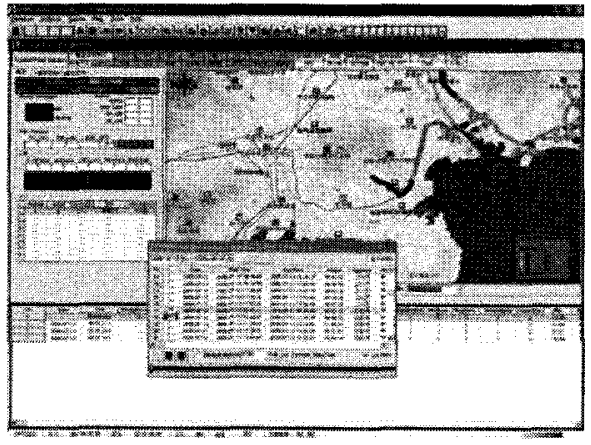

a. 측정 결과 선택

a. Selection of Measured Result

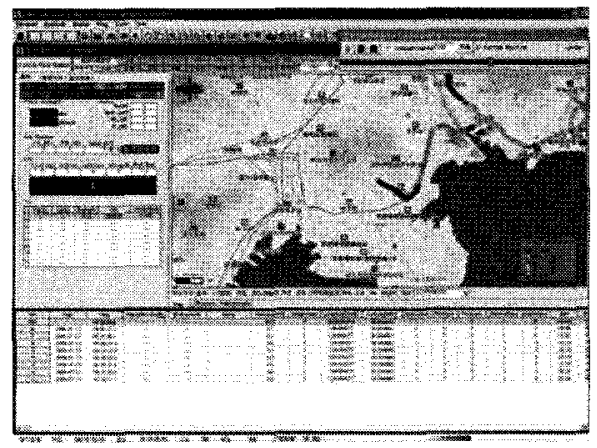

b. 재생 과정

b. Replay Process

그림 18. 커버리지 측정 시스템의 측정 결과 재생

Fig. 18. Replay of Measured Results by Coverage Measurement System

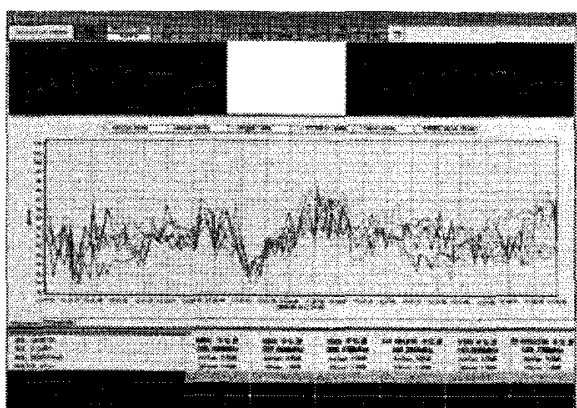

a. 전계강도 재생

a. Replay of Field Strength

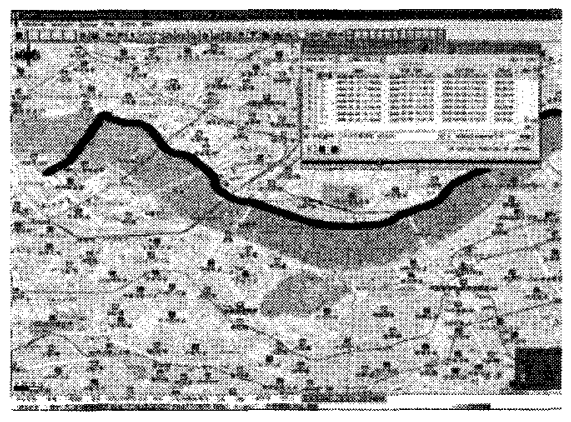

b. 재생 과정

b. Replay Process

그림 19. 멀티 측정 시스템의 측정 결과 재생

Fig. 19. Replay of Measured Results by Multi Measurement System

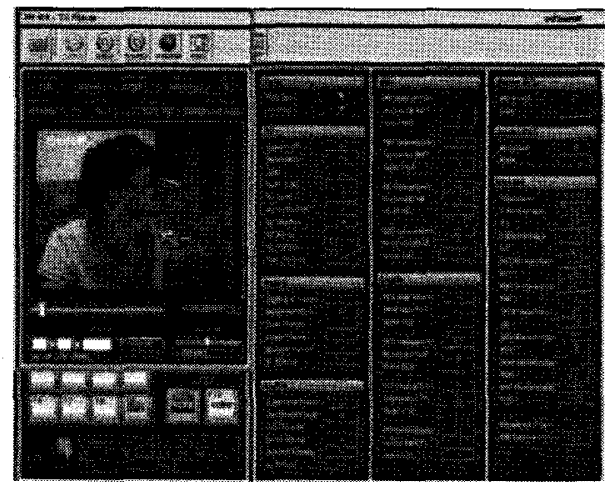

그림 20. 비디오 측정 시스템의 측정 결과 재생

Fig. 20. Replay of Measured Results by Video Measurement System

오프셋, 해당 구간의 측정 당시 시간, 해당 구간의 오류 발
생 여부에 대한 정보로 구성되며, 측정과 동시에 자동으로 생성된다. 오류가 발생한 비디오 스트림과 이에 대해 생성 된 링크 파일의 예는 <그림 $21-\mathrm{a}, \mathrm{b}>$ 와 같다.

비디오 스트림과 측정 결과의 재생 지점을 일치시키기 위한 방법은 다음과 같다. 비디오 스트립을 재생하면서 재 생 지점의 바이트 오프셋을 계산하고, 계산된 바이트 오프 셋을 이용하여 링크 파일을 검색한다. 링크 파일에서 해당 위치를 찾아 당시의 측정 시간 정보를 얻고, 측정결과 $\mathrm{DB}$ 를 검색하여 해당 시간의 측정 결과를 재생한다.

링크 파일에 기록된 오류 발생 여부에 대한 정보를 이용 하면 비디오 스트림의 오류 지점만을 추적하여 재생하는 것이 가능하다. 링크 파일에서 오류가 발생한 구간을 찾고, 해당 구간의 바이트 오프셋 정보를 이용하여 비디오 스트 


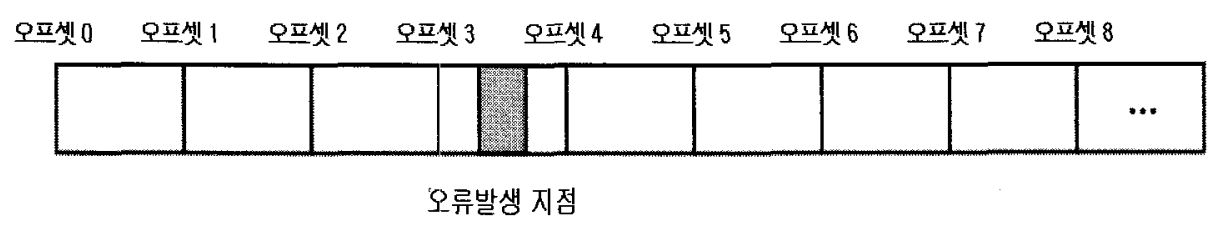

a. 오류 비디오 스트림

a. Errored Video Stream

\begin{tabular}{|c|c|c|c|c|c|c|c|c|}
\hline 오프셋 0 & 오프셋 1 & 오프셋2 & 오프셋3 & 오프셋4 & 오프셋 5 & 오프셋6 & 오프셋7 & $\ldots$ \\
\hline 시간 0 & 시간 1 & 시간 2 & 시간 3 & 시간 4 & 시간 5 & 시간 6 & 시간 7 & $\ldots$ \\
\hline 오류쯜래그0 & 오류플래그1 & 오류플래그2 & 오류플래그 3 & 오류플래그4 & 오류플래그 5 & 오류플래그 6 & 오류플래그7 & $\ldots$ \\
\hline
\end{tabular}

b. 링크 파일 구조

b. Link File Structure

그림 21. 오류 비디오 스트림과 링크 파일 구조

Fig. 21. Errored Video Stream and Link File Structure

림에서 해당 구간을 추적하고 재생한다. 또한 동시에 비디

오 스트림 재생 지점에 해당하는 측정 시간을 링크 파일 에서 검색하고, 이를 이용하여 측정 결과 $\mathrm{DB}$ 에서 대응하는 측정 결과를 검색하고 재생한다. 이러한 기능을 이용하면 수신 상태가 불량한 지점만을 효율적으로 추출하여 분석하 는 것이 가능하다.

링크 파일을 기록하는 간격에 따라 오류 발생 지점을 추적하는 정확도와 비디오 스트림과 측정 결과의 재생 일 치 정도가 변화한다. 링크 파일의 기록간격이 측정 시스템 의 측정 간격 보다 큰 경우에는 재생 과정에서 제외되는 측정 결과가 발생하여 정확한 재생이 불가능하게 되고, 기 록간격이 측정 간격 보다 작지만 오류 발생 간격보다 큰 경우에는 오류 발생 지점을 추적하는 정확도가 감소하게 된다. 링크 파일 기록 간격은 사용자 입력에 의하여 조절 가능하다.

\section{V. 필드 테스트에서의 적용}

제안한 시스템은 KBS의 T-DMB SFN과 중계망 구축, 수 도권 6개 사업자 공동 전파 분포 조사, $\mathrm{KBS}$ 의 지역 T-DMB
실험방송에 대한 전파 분포 조사에 적용되어 성능 및 안정 성이 검증되었다.

$\mathrm{KBS}$ 의 T-DMB SFN 구축은 2005년 11월에 수도권에서 실시되었다. ETS 300 799에 정의된 T-DMB SFN을 구축 하기 위한 조건과 원거리 송신기들의 간섭이 주로 측정 되었다. 다른 송신소에(관악산, 남산, 용문산) 위치한 3개 의 송신기들이 채널 $12 \mathrm{~B}(207.008 \mathrm{MHz})$ 에서 $\mathrm{SFN}$ 을 구성 하였다.

수도권 6개 사업자 공동 전파 분포 조사는 2006년 1 3 월에 커버리지 산출과 T-DMB 중계 시설의 공동 구축을 위 한 기초 자료 확보를 목적으로 실시되었다. 필드 테스트는 T-DMB IMAS를 탑재한 4대의 측정 차량에 의해 수행되었 고, 6 개 T-DMB 채널 $(8 \mathrm{~A}, 8 \mathrm{~B}, 8 \mathrm{C}, 12 \mathrm{~A}, 12 \mathrm{~B}, 12 \mathrm{C})$ 에 대한 전계강도와 스펙트럼을 동시에 측정하였다.

$\mathrm{KBS}$ 의 지역 $\mathrm{T}-\mathrm{DMB}$ 실험 방송에 대한 전파 분포 조 사는 실용화 시험국으로 운용되는 4개 지역(부산, 광주, 춘천, 제주)과 인접 지역에서 T-DMB 커버리지를 산출 하기 위한 목적으로 2006년 6 7월에 실시되었다. 대표 적으로 부산에서 측정된 결과는 다음과 같다(표 5 , 표 6, 그림 22). 
표 5. 송신 시설

Table 5. Transmission Facilities

\begin{tabular}{|c|c|c|c|c|c|c|}
\hline 송신소 & 채널 & $\begin{array}{c}\text { 출력 } \\
(\mathrm{kW})\end{array}$ & $\begin{array}{c}\text { 안테나 이득 } \\
(\mathrm{dBi})\end{array}$ & $\begin{array}{c}\text { 안테나 판넬 } \\
(\mathrm{N}, \mathrm{E}, \mathrm{S}, \mathrm{W})\end{array}$ & $\begin{array}{c}\text { 해발고 } \\
(\mathrm{m})\end{array}$ & $\begin{array}{c}\text { 안테나 실효고 } \\
(\mathrm{m})\end{array}$ \\
\hline 부산 황령산 & $\begin{array}{c}12 \mathrm{~B} \\
(207.008)\end{array}$ & 2 & 9.02 & $\begin{array}{c}2 \mathrm{D}-12 \mathrm{P} \\
(4-2-2-4)\end{array}$ & 474 & 74 \\
\hline
\end{tabular}

표 6. 전계강도별 수신율

Table 6. Reception Rate as Field Strength Changes

\begin{tabular}{|c|c|c|c|c|c|}
\hline 총 이동 거리 $(\mathrm{km})$ & \multicolumn{5}{|c|}{1209.891} \\
\hline 전계강도 $(\mathrm{dBuV} / \mathrm{m})$ & $37 \sim$ & $45 \sim$ & $50 \sim$ & $65 \sim$ & $75 \sim$ \\
\hline 커버리지 거리 $(\mathrm{km})$ & 1028.364 & 721.016 & 561.807 & 293.053 & 194.953 \\
\hline 수신율 $(\%)$ & 85 & 60 & 46 & 24 & 16 \\
\hline
\end{tabular}

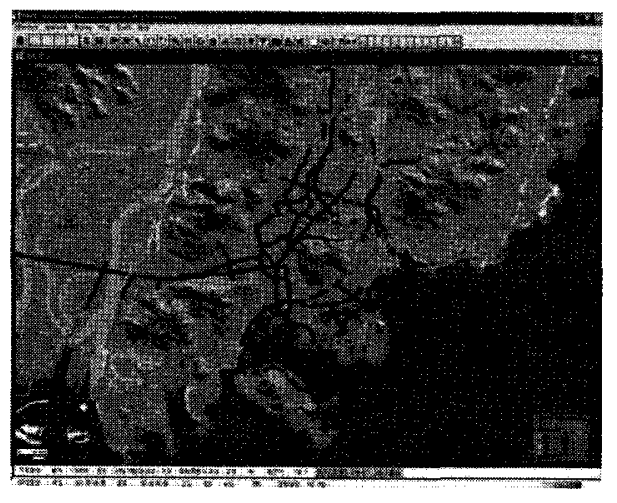

그림 22. 전자지도 상의 전계강도 분포

Fig. 22. Field Strength Distribution on The Electronic Map

\section{Vl. 결론}

본 논문에서는 T-DMB SFN의 특성과 기존 측정 시스템 들의 문제점을 분석하고, $\mathrm{T}-\mathrm{DMB}$ 를 위한 새로운 $\mathrm{DMB}$ 측 정 시스템에 대한 요구 사항을 도출하였다. 그리고 이를 기 반으로 지상파 $\mathrm{DMB}$ 를 위한 통합 측정 및 분석 시스템을 제안하였다.

제안한 시스템은 커버리지 측정 시스템, 멀티 측정 시스 템, 비디오 측정 시스템, 분석 시스템, 재생 시스템으로 구 성되었으며, T-DMB 방송망 구축, 수신 품질의 측정과 커버 리지 산출을 지원한다.

제안한 시스템은 $\mathrm{KBS}$ 의 T-DMB 방송망 구축과 필드테
스토 적용되었으며, 그 결과를 본 논문에 기술하였다. 향후 에도 제안한 시스템을 T-DMB 방송망 관리와 난시청 해소 에 지속적으로 적용할 예정이다.

\section{참 고 문 헌}

[1] “지상파 디지털멀티미디어방송(DMB) 비디오 송수신 정합표준," TTAS.KO-07.0026/R1, Dec. 2006

[2] "Radio Broadcasting Systems; Digital Audio Broadcasting(DAB) to mobile, portable and fixed receivers," ETSI EN 300401 V1.4.1, June, 2006

[3] "Digital Audio Broadcasting(DAB); Guidelines and rules for implementation and operation; Part 3: Broadcast network," ETSI TR 101 496-3 V1.1.2, May, 2001

[4] Wolfgang Hoeg, Thomas Lauterbach, "Digital Audio Broadcasting: Principle and Application of Digital Radio," 2nd Edition, Wiley

[5] C. Gandy, "DAB: an introduction to the Eureka DAB System and a guide to how it works," BBC R\&D White Paper, June, 2003

[6] "Digital Audio Broadcasting(DAB); Distribution interfaces; Ensemble Transport Interface(ETT)," ETSI ETS 300 799, Sep. 1997

[7] R\&S,http://www.rohdeschwarz.com/www/dev_center.nsf/html/romes3frame

[8] VAD, http://www.vadgmbh.de/english/umodire.htm

[9] Sang-Hun Kim et al, "Effective BER Measurement System for Terrestrial DMB," Journal of Broadcasting Engineering, vol. 8, no. 3, pp. 250-258, Sep. 2003

[10] Sang-Hun Kim et al, "The Development of Integrated Mobile Measurement System for Terrestrial DMB," Journal of Broadcasting Engineering, vol. 9, no. 4, pp. 411-423, Dec. 2004

[11] "Digital Audio Broadcasting System - Specification of the Receiver Data Interface(RDI)," CEI/IEC 62105 Dec. 1999

[12] "Information technology - Coding of audio-visual objects - Part 1: Systems," ISO/IEC 14496-1, 2004 
저 자 소 개

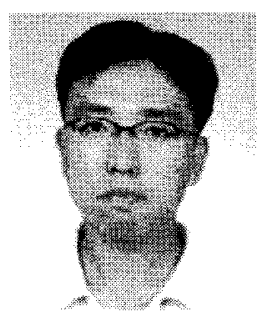

\section{김 상 훈}

-1998년 8월 : 고려대학교 전자공학개공학사)

-2001년 8월 : 한국과학기술원 전기 및 전자공학과(공학석사)

현재 : KBS 방송기술연구팀

- 주관심분야 : DMB 다중화, OFDM 전송, 모바일 방송

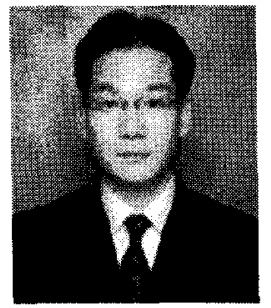

\section{김 영 민}

-1998년 2월 : 고려대학표 컴퓨터학과이학사

-2000년 2월 : 고려대학표 컴퓨터학과이학석사)

-2002년 12월 : 한국국방연구원 연구원

현재 KBS 방송기술연구팀

· 주관심분야 : 디지털TV 방송 시스템, 멀티미디어 서비스

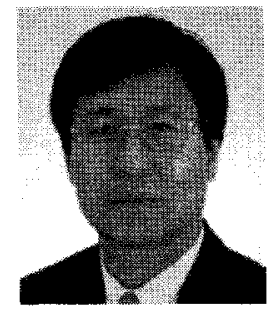

\section{김 만 식}

-1979년 2월 : 서울대학교 전자공학괘(공학사)

-1981년 2월 : 한국과학기술원 전기 및 전자공학과공학석사)

- 현재 : KBS 방송기술연구탐 선임

· 주관심분야 : 디지털방송(DTV, DMB), 방송제작 기술

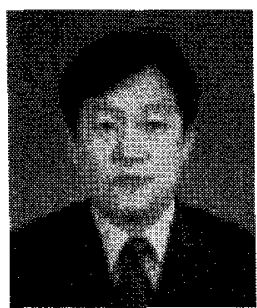

\section{김 규 영}

-1981년 11월 : KBS 입사

-KBS 방송망 운용국 디지털 차장

KBS 대구 제작기술 부장

KBS 안동 기술 부장

현재 : KBS 디지털전환탐 선임

주관심분야 : 디지털 방송 시스텝, 방송파 전파 설계 